Koch, L. 1920: Stratigraphy of Northwest Greenland. Meddr dansk geol. Foren. 5, 78 pp.

Ross, J. 1819: A Voyage of discovery ... Isabella and Alexander, ... exploring Baffin's Bay ... North-West Passage. London: John Murray.

T. F.,

Geological Survey of Canada,

588 Booth Street,

Ottawa, Ontario K1A OE4,

Canada.

\title{
Sedimentological observations in Cretaceous and Tertiary rocks in the northern part of the West Greenland sedimentary basin
}

\author{
Frank Andreasen
}

As part of the programme to produce geological maps at a scale of 1:100000 field work was carried out in the eastern part of the area covered by map sheet 71 V.1 N (Svartenhuk Halvø). Reconnaissance work was carried out in parts of the area covered by map sheet 72 V.1S.

At a number of localities detailed sedimentological sections were measured at a scale of 1:100. Emphasis was laid on the registration of primary sedimentary structures and grain-size distribution. A large number of palaeocurrent measurements were carried out in order to describe the depositional environments and to enable an interpretation of the development and geometry of the sedimentary basins to be made.

\section{Itsako}

In spite of relatively poor exposures a more or less continuous section could be measured through both Cretaceous and Tertiary rocks on the north-eastern slope of the Itsako peninsula. Formal names have not yet been given to the Cretaceous and Tertiary rocks in the Svartenhuk area.

The lower part of the Cretaceous sedimentary sequence is dominated by medium and coarse grained arkosic sandstones deposited by large braided rivers. Transport directions were towards the west and north-west. The middle part of the sequence consists of sandstones similar to the lower part but deposited between thick units of black marine mudstones with abundant plant fragments. The mudstone sedimentation was a consequence of basinal downwarp resulting in an upstream trapping of fluvial sands. The upper part of the Cretaceous sequence on Itsako consists of a thick unit of black mudstones.

In the (?)Paleocene (Croxton, 1978) a 5-10 m thick coarse conglomerate with well rounded boulders up to $50 \mathrm{~cm}$ in diameter initiates Tertiary sedimentation in the area as a result of renewed tectonic activity. The conglomerate is in turn followed by fine grained sandstones and by a thick unit of black mudstones with intercalations of fine grained 
sandstones. The mudstone sedimentation was interrupted by tuff sedimentation (Gry in Rosenkrantzet al., 1942) and finally by hyaloclastites of which a small occurrence was found on the top of the Itsako peninsula.

\section{Umîarfik}

The Cretaceous rocks in the northern part of Svartenhuk Halvø, which consist of black marine shales, were not dealt with sedimentologically. The Tertiary sediments were studied in detail. Although interbasaltic sediments are present along the major part of Umîarfik fjord and at many localities in the northern part of Svartenhuk Halvø, detailed sedimentological investigations can only be made at a few localities where the exposures are suitable. The interbasaltic sediments in the area investigated mark a long pause in the volcanic events following the extrusion of olivine-rich basalts belonging to the lower formation (cf. Pulvertaft \& Clarke, 1966). The interbasaltic sediments can be divided into two main groups based on lithology, namely those with a basement source area and those with a mainly volcanic source area. The first group of sediments is the most important.

On the north side of Simiútap kûa the interbasaltic sedimentary sequence contains between three and five allochthonous coal layers of considerable thickness. The first of these, which is more than $3.5 \mathrm{~m}$ thick, is deposited directly on the top of a more than $30 \mathrm{~m}$ thick columnar jointed lava flow with a palaeoflow direction towards the north-east (based on the direction of bending and inclination of columns). The second coal layer is $5 \mathrm{~m}$ thick and the third about $1.5 \mathrm{~m}$ thick. All three coal layers are found within a sequence less than $30 \mathrm{~m}$ thick. Because of the very bad exposures and limited time available it was not possible to determine either the thickness of the fourth and fifth coal layers or the lateral extent of any of the coal layers.

The sedimentary environment in which the coals accumulated probably was some kind of a lake or a series of lakes dammed by huge lava flows poured out on to a broad flood-plain. Block tilting should also be considered as a possible cause of lake formation.

In the inner part of Umiarfik in the same stratigraphic level as the interbasaltic sediments, a thick fluvial sandstone sequence with layers of black carbonaceous mudstone containing coal seams is present. This sequence rests on the basement. Palaeocurrent data from this locality indicate westerly transport directions.

\section{References}

Croxton, C. A. 1978: Report of field work undertaken between $69^{\circ}$ and $72^{\circ} \mathrm{N}$, central West Greenland in 1975 with preliminary palynological results. Unpubl. int. GGU report, $99 \mathrm{pp}$.

Pulvertaft, T. C. R. \& Clarke, D. B. 1966: New mapping on Svartenhuk peninsula. Rapp. Grønlands geol. Unders. 11, 15-17.

Rosenkrantz, A., Noe-Nygaard, A., Gry, H., Munck, S. \& Lauersen, D. 1942: A geological reconnaissance of the southern part of the Svartenhuk peninsula, West Greenland. Meddr Grønland 135 (3), 72 pp. 